\title{
Anticancer Potential of Ethyl Acetate Extract Fractions of Ipomoea horsfalliae Hook on DMBA- Induced Breast Cancer Model
}

\author{
Muhammed ashraf V. K. ${ }^{1, *(\mathbb{D})}$, Kalaichelvan V. K. ${ }^{1 \mathbb{C}}$, Venkatachalam V. V. ${ }^{1(\mathbb{D})}$ \\ 1 Department of Pharmacy, Annamalai University, Annamalai Nagar-608002, Tamil Nadu, India \\ * Correspondence: ashrafvkclt@gmail.com (M.A.V.K.);
}

Scopus Author ID 57218137130

Received: 25.07.2021; Revised: 25.09.2021; Accepted: 30.09.2021; Published: 19.11.2021

\begin{abstract}
The genus Ipomoea is distributed globally and honored as the largest genus of the family Convolvulaceae. Several varieties of this family have been shown to be effective in treating various diseases, including cancer. This research aimed to explore the anticancer activity of ethyl acetate fractions of Ipomoea horsfalliae Hook (EAIH) in female Sprague-Dawley rats. 7, 12-dimethylbenz (a) anthracene (DMBA) was used to produce breast cancer. The Fractions were selected based on the cytotoxicity analysis in vitro, which was reported in our earlier studies. The study employed two dosages of EAIH (25 and $50 \mathrm{mg} / \mathrm{kg}$ ). Biochemical, hematological, and antioxidant characteristics were investigated. A decrease in mean tumor volume and tumor weight was detected in EAIH treated groups. The blood parameters were seen as normal. In both DMBA and doxorubicin groups, malondialdehyde was increased, and the level was significantly reduced in EAIH-treated groups. The effect of catalase was shown to be diminished in the groups given DMBA and doxorubicin but normal in the EAIH groups. Nitrate and nitrite levels increased in the DMBA control groups but were normal in the others. There was less necrosis and infiltration in breast tissues treated with doxorubicin as well as in EAIH. In animals treated with EAIH, the therapeutic effect was found to be dose-dependent. The therapies helped to repair some of the altered breast patterns. The study concludes that I. horsfolliae may be a potential anticancer candidate and need to explore further.
\end{abstract}

Keywords: Ipomoea horsfalliae Hook; breast cancer; EAIH; anticancer potential; DMBA induced model.

(C) 2021 by the authors. This article is an open-access article distributed under the terms and conditions of the Creative Commons Attribution (CC BY) license (https://creativecommons.org/licenses/by/4.0/).

\section{Introduction}

Extreme cell proliferation, wrong regulation of cellular differentiation, and insufficient apoptosis are all features of breast cancer [1]. Breast cancer is one of the most common cancers in women, accounting for $25 \%$ of all new cases (1.7 million) and $15 \%$ of cancer deaths [2]. On the other hand, inflammation and angiogenesis have been proven to be critical for primary cancer development, invasion, and metastases in a number of investigations over the last decade $[3,4,5]$. Chemically incited rat models of mammary malignancy have been widely utilized to imitate human breast carcinogenesis for many years. The mammary glands of a few rodent strains, primarily Sprague-Dawley and Wistar rats, are more vulnerable to chemical carcinogens, with DMBA and N-methyl nitrosourea being the two most commonly used breast cancer inducers [6,7]. The tumor-induced by this model resembles human estrogen-dependent breast cancer in terms of morphology and histology [8]. Several chemoprevention indicators 
have been developed. They depend on how chemopreventive drugs can use one or more combination mechanisms to prevent carcinogenic cascade, such as promoting enzymes to detoxify carcinogenic substances, scavenge reactive oxygen species, enhance apoptosis, and suppress apoptosis the proliferation of cells $[9,10]$.

Free radicals play a critical role in the development of tumors by direct chemical reactions or changes in cell metabolism, and their scavengers can suppress cancer cells in various stages of carcinosis. Antioxidants can also regulate reactive oxygen (ROS) toxicity as an impediment to ROS formation [11]. The original strategy to chemotherapy involves individual alkylating and antimetabolite therapy which is now replaced by combination therapy since two or more medicines were demonstrated in conjunction with improved outcomes[12]. Antioxidants can be used to limit the toxicity of reactive oxygen (ROS) by the impediment in ROS generation. Modern breast cancer management or treatment includes surgery, chemotherapy, radiation treatment, hormonal treatment, and anti-Her-2 medication [13,14]. However, the enormous treatment options and breakthroughs in breast malignancy therapy continue to generate several reactions that badly affect the quality of life [15]. Thus, the search for treatments that can reduce side effects, either alone or in conjunction with medications already used to treat breast cancer, has a lot of potential in the drug discovery process.

The species I. horsfalliae belongs to the family Convolvulaceae, which is well known as "Morning glory" which has simple and dark green alternate leaves. Its inflorescences have the color of deep fuchsia and grow on the end of the branches [16]. This species comes from the West Indian islands and is grown worldwide as a blooming climber in the tropics. They have attractive red-purple flowers and bright dark green leaf and are therefore used mainly for ornamental purposes [17]. The I. horsfolliae species are not edible; their flowers are reported for photoprotective activity [18]. In addition to medicinal importance, certain plants also belong to the Ipomoea genus used for crops and industrial applications. For example, I. Aquatic for removing Auramine $\mathrm{O}$ dye as a green adsorbent [19]. In the paper industry, I. carnea is used [20]. The role of I. Cairica and I. tricolor for allelopathic crop weed effect have been reported [21,22], I. Carnea is used as a fuel source [23]. The literature does not contain scientific evidence or reports about the benefits of $I$. horsfalliae in breast cancer. We hypothesized that $I$. horsfalliae aerial parts may include numerous phytochemicals with anticancer potential and can heal breast cancer. Therefore, this work aims to assess the anticancer activity of I. horsfolliae using the DMBA induced model for breast cancer.

\section{Materials and Methods}

\subsection{Chemicals.}

The DMBA was supplied from sigma chemical company St. Louis, MO, USA. All other chemical materials used in this study are of analytical quality, obtained from Himedia private laboratories ltd., Mumbai, India

\subsection{Collection, extraction, and fractionation of plant material.}

Aerial parts of Ipomoea horsfalliae Hook were obtained locally from Calicut district (Kerala, India). Extraction and fractionation methods used have already been reported in our previously published paper [24]. The fractions with better cytotoxicity on Human breast cancer cells (MCF-7) in in vitro studies were used for the present studies. This study used two doses of ethyl acetate fractions of $I$. horsfalliae (EAIH) $(25$ and $50 \mathrm{mg} / \mathrm{kg})$. 
2.3. Selection of experimental animals.

Female Sprague-Dawley rats (125-175 g body weight) were employed. The studies were prepared and carried out in accordance with ethical guidelines approved by Institutional Animal Ethical Committee (IAEC).

\subsection{Tumor induction and drug treatment.}

DMBA is a potent carcinogenic agent used in animals to induce tumors at a single dose (30 mg/kg). The DMBA was administered orally with an intragastric tube to the respective groups. They developed tumors after 14 weeks. The EAIH $25 \mathrm{mg} / \mathrm{kg}$ and EAIH $50 \mathrm{mg} / \mathrm{kg}$ ( test samples) were administered orally for four weeks. Rats selected for the study were fasted overnight and sacrificed. The blood was collected for further biochemical studies, and the serum was isolated.

\subsection{Experimental design.}

For animal experiments and evaluation of different parameters, previously reported methods were carried out [25]. Animals are grouped, and treatment was given as follows: Group I: $0.25 \%$ of carboxymethyl cellulose (CMC) was received orally and is considered a normal control; Group II: Mammary tumor-induced rats by DMBA; Group III: DMBA administered mammary tumor groups. Animals are treated with doxorubicin once weekly for 4 weeks ( $2 \mathrm{mg} / \mathrm{kg}$, i.p); Groups IV and V: DMBA administered rats treated with EAIH $25 \mathrm{mg}$ $/ \mathrm{kg}$ and EAIH $50 \mathrm{mg} / \mathrm{kg}$ respectively for 4 weeks (suspended at $0.25 \%$ CMC) p.o. Drug administration began when tumors became stable and palpable.

\subsection{General observations.}

Throughout the experiment, the animal's total body weight gain was recorded every week. At the end of the study, animals were sacrificed, and different organs were dissected and weighed out, including the liver, kidneys, spleen, and heart.

\subsection{Tumor weight and tumor volume.}

To assess tumors, Vernier calipers were used [26], and the volume of tumors was measured as follows,

The volume of tumor $=(\mathrm{L} \times \mathrm{W} 2) / 2$, where $\mathrm{L}$ and $\mathrm{W}$ deliberated as length and width in centimeter, respectively.

\subsection{Hematological parameters.}

The blood from the animals' retro-orbital plexus was collected and measured with the help of a veterinary blood cell counter.

\subsection{Antioxidant and biochemical evaluation in breast tissue.}

The breast tissues were removed, and super cold PBS was used to wipe, blot, and gauge the blood. The tissue homogenate was prepared in a potassium chloride solution. The homogenate obtained was centrifuged for $10 \mathrm{~min}$ at $8000 \mathrm{rpm}\left({ }^{\circ} \mathrm{C}\right)$ to get a clear supernatant, which was used to estimate antioxidant and biochemical parameters.

2.10. Assessment of nitric oxide (NO). 
The nitrogen oxide levels of the breast tissue were evaluated by measuring the cumulative nitrate and nitrite concentrations. To estimate the nitrite content, the Griess reagent method was used. The Griess reagent $(100 \mu \mathrm{L})$ and the homogeneous tissue $(100 \mu \mathrm{L})$ were incubated at $37 \mathrm{oC}$ for $20 \mathrm{~min}$, the absorbance was read at $540 \mathrm{~nm}$, and the nitrite content was derived from the standard sodium nitrite curve [27]. $100 \mu \mathrm{L}$ of homogenate from breast tissue was incubated at $45^{\circ} \mathrm{C}$ for 60 min with Griess reagent and vanadium (III) chloride. To measure absorbance at $540 \mathrm{~nm}$, a microplate reader was employed.

\subsection{Lipid peroxidation analysis.}

Briefly, 8.1 percent of sodium dodecyl sulfate $(200 \mu \mathrm{L}), 20$ percent acetic acid $(1.5 \mathrm{ml})$ solution, and 0.8 percent aqueous thiobarbituric acid solution $(1.5 \mathrm{~mL})$ were treated with breast tissue homogenate $(200 \mu \mathrm{L})$. The total volume is then composed of up to $4 \mathrm{ml}$ of distilled water and then heated at $95{ }^{\circ} \mathrm{C}$ for $1 \mathrm{~h}$. The cooled mixture was added to the distilled water $(1 \mathrm{ml})$, n-butanol (5ml), and pyridine mixture. The mixture was heavily shaken and then centrifuged for 5 minutes at a rate of $5000 \mathrm{rpm}$. The top layer was discarded, and the absorbance measurement was at $532 \mathrm{~nm}$ using the UV spectrophotometer [28].

\subsection{Assessment of catalase level.}

The breast tissue homogenate was then added to $3 \mathrm{ml}$ of hydrogen peroxide solution for catalase level evaluation. At $240 \mathrm{~nm}$, the absorbance was recorded [29].

\subsection{Assessment of serum biomarkers.}

For the assessment of Creatinine, Alanine transaminase (ALT), Urea and Aspartate aminotransferase (AST), appropriate autoanalyzer kits (Roche Diagnostics, Indianapolis, USA) were used.

\subsection{Histopathological evaluation of breast tissues.}

In order to support the histopathological assessment of the breast, tissues were fixed in neutral buffered formalin (10 percent), washed with alcohol, and cleared with xylene. (RM22545, Leica Microsystems GmbH, Wetzlar) Paraffin wax impregnated tissue, and a $5 \mu \mathrm{m}$ section were then fixed on the slides and dewaxed with the help of xylene and rehydrated by using alcohol using a rotating microtome. The tissues were then stained with hematoxylin and eosin. In the tubular alveolar pattern, the slides were monitored and interpreted under a microscope by an expert (pathologist) to identify the type of carcinoma, immune cell infiltration, necrosis, and hemorrhage.

\subsection{Statistical analysis.}

The one-way variance analysis (ANOVA), followed by "Tukey's post hoc test" with GraphPad Prism 6.05 version, was used to evaluate statistical comparisons and significance. Two-way ANOVA was used to examine the effect on tumor growth, followed by "Tukey's post hoc test." All outcomes were presented as Mean \pm SEM, considering the significance value of $p>0.05$. 


\section{Results and Discussion}

\subsection{Treatment impact on organ weight and body mass.}

In our study, the liver, heart, and kidneys' weight between treatment and control groups were not significantly changed. However, the spleen's weight was significantly decreased in the doxorubicin administered groups compared with DMBA and normal control groups. There was no remarkable variation in body weight seen among all groups (Table 1).

Table 1. Impact of the treatments in Sprague Dawley rats on body weight and organ weight.

\begin{tabular}{l|l|l|l|l|l}
\hline Groups. & $\begin{array}{l}\text { Heart } \\
(\mathbf{g})\end{array}$ & $\begin{array}{l}\text { Spleen } \\
(\mathbf{g})\end{array}$ & $\begin{array}{l}\text { Kidney } \\
(\mathbf{g})\end{array}$ & $\begin{array}{l}\text { Liver } \\
(\mathbf{g})\end{array}$ & $\begin{array}{l}\text { Growth in } \\
\text { body weight }(\boldsymbol{\%})\end{array}$ \\
\hline Normal Control. & $0.85 \pm 0.77$ & $0.74 \pm 0.64$ & $0.77 \pm 0.32$ & $5.23 \pm 0.32$ & $116.67 \pm 5.76$ \\
\hline DMBA control & $0.81 \pm 0.28$ & $0.77 \pm 0.33$ & $0.73 \pm 0.23$ & $5.45 \pm 0.23$ & $126.32 \pm 5.22$ \\
\hline Doxorubicin & $0.78 \pm 0.67$ & $0.34 \pm 0.45^{\mathrm{a}, \mathrm{b}}$ & $0.78 \pm 0.34$ & $5.34 \pm 0.24$ & $117.78 \pm 5.82$ \\
\hline EAIH 25mg/kg & $0.83 \pm 0.24$ & $0.73 \pm 0.47$ & $0.74 \pm 0.75$ & $5.55 \pm 0.67$ & $120.47 \pm 4.65$ \\
\hline EAIH $50 \mathrm{mg} / \mathrm{kg}$ & $0.88 \pm 0.35$ & $0.75 \pm 0.63$ & $0.76 \pm 0.48$ & $5.78 \pm 0.37$ & $121.17 \pm 5.75$
\end{tabular}

All the values are measured in mean \pm SEM; ${ }^{\mathrm{a}} p<0.05$ compared to normal control groups; ${ }^{\mathrm{b}} p<0.05$ compared to DMBA Control; $n=6$.

\subsection{Treatment impact on tumor growth and the weight of tumors.}

The impression of the treatment on tumor progression was measured by a reliable (each week) evaluation of tumor volume. The rats were sacrificed, and parameters such as mean tumor weight and mean tumor volume was observed. After one week of treatment, doxorubicin decreased the tumor volume significantly. Compared to control rats treated with DMBA alone, all animals treated with EAIH significantly reduced the mean tumor volume and mean tumor weight at both doses (Figures 1 and 2). In rats treated with EAIH $25 \mathrm{mg} / \mathrm{kg}$ and EAIH $50 \mathrm{mg} / \mathrm{kg}$, tumor volume decreased significantly after three weeks of EAIH treatment when connected with DMBA control groups. In the fourth week, the most significant decrease in tumor volume was seen.

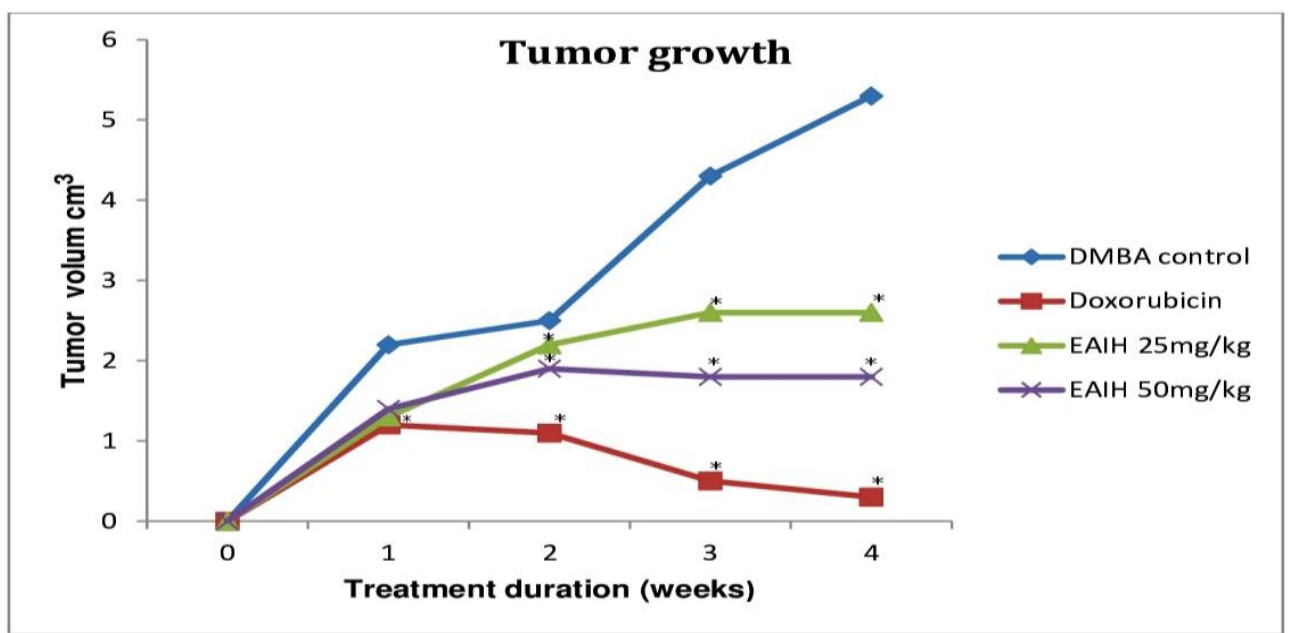

Figure 1. Influence of EAIH and Doxorubicin on tumor development. The drug treatments were continued for four weeks period. All treatments began after the tumor growth was palpable, and the start of drug treatment was measured as 0 th week. All values are expressed as mean \pm SEM; ${ }^{*} p<0.05$ compared to DMBA Control; $n=6$. 


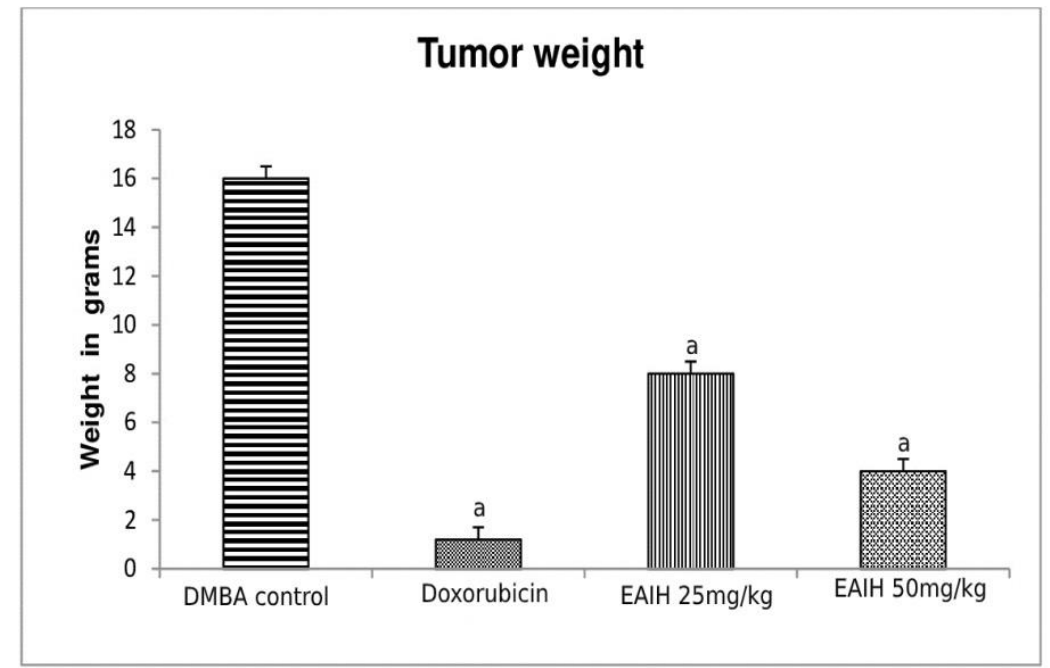

Figure 1. Influence of the treatments on mean tumor weight; All the values are given as mean $\pm \mathrm{SEM} ;{ }^{\mathrm{a}} p<0.05$ compared to DMBA Control; $n=6$.

\subsection{Impact of treatment on blood parameters.}

The Red blood cell counts (RBC) and hemoglobin levels were significantly reduced in groups administered with doxorubicin when compared with normal control. It may be a clear consequence of the bone marrow toxicity of doxorubicin. No significant changes in any other blood parameters were produced at both doses of EAIH (Table 2).

Table 2. Impact of treatments in Sprague Dawley rats on blood parameters.

\begin{tabular}{l|l|l|l|l}
\hline Groups. & $\mathbf{R B C}\left(\times \mathbf{1 0}^{\mathbf{6}} / \boldsymbol{\mu l}\right)$ & $\mathbf{W B C}\left(\times \mathbf{1 0}^{\mathbf{3}} / \boldsymbol{\mu l}\right)$ & Platelets $\left(\times \mathbf{1 0}^{\mathbf{3}} / \boldsymbol{\mu l}\right)$ & $\mathbf{H b}(\mathbf{g} / \mathbf{d l})$ \\
\hline Normal Control. & $8.35 \pm 0.32$ & $12.45 \pm 0.24$ & $417 \pm 19.37$ & $12.23 \pm 0.76$ \\
\hline DMBA control & $7.76 \pm 0.54$ & $11.53 \pm 0.38$ & $465 \pm 23.76$ & $11.53 \pm 0.56$ \\
\hline Doxorubicin & $5.44 \pm 0.74$ & $11.64 \pm 0.54$ & $417 \pm 14.56$ & $8.54 \pm 0.34$ \\
\hline EAIH 25mg/kg & $7.77 \pm 0.85$ & $12.56 \pm 0.34$ & $426 \pm 22.64$ & $12.67 \pm 0.21$ \\
\hline EAIH 50mg/kg & $8.54 \pm 0.76$ & $11.63 \pm 0.84$ & $433 \pm 16.76$ & $12.48 \pm 0.56$
\end{tabular}

All the values given as mean \pm SEM; ${ }^{a} p<0.05$ compared to normal control; $n=6$.

\subsection{Impact on catalase levels and lipid peroxidation in breast tissue.}

In the animal groups treated with DMBA and doxorubicin, catalase activity in breast tissue was significantly reduced compared with normal controls. However, in comparison with normal control, the catalase activity of the EAIH treated animal groups was not significant. In both doxorubicin and DMBA control-treated rats, the level of malondialdehyde ( MDA) was significantly increased. Compared to the normal control groups, the difference in MDA levels in the EAIH treated groups at both doses did not produce any significant changes (Table 3).

Table 3. Treatment impact on catalase levels and lipid peroxidation on breast tissue.

\begin{tabular}{l|c|c}
\hline \multicolumn{1}{c|}{ Groups } & Catalase (U/mg of protein) & $\begin{array}{c}\text { MDA } \\
\text { (nmol MDA/mg of protein) }\end{array}$ \\
\hline Normal Control & $43.36 \pm 1.42$ & $1.08 \pm 0.21$ \\
\hline DMBA control & $24.47 \pm 1.75^{\mathrm{a}}$ & $2.52 \pm 0.86^{\mathrm{a}}$ \\
\hline Doxorubicin & $24.03 \pm 1.32^{\mathrm{a}}$ & $2.79 \pm 0.48^{\mathrm{a}}$ \\
\hline EAIH $25 \mathrm{mg} / \mathrm{kg}$ & $43.63 \pm 1.86^{\mathrm{b}}$ & $0.93 \pm 0.31^{\mathrm{b}}$ \\
\hline EAIH $50 \mathrm{mg} / \mathrm{kg}$ & $46.53 \pm 1.67^{\mathrm{b}}$ & $0.90 \pm 0.28^{\mathrm{b}}$ \\
\hline
\end{tabular}

All the values are given as mean \pm SEM; ${ }^{\mathrm{a}} p<0.05$ compared to normal control; ${ }^{\mathrm{b}} p<0.05$ compared to DMBA control; $n=6$. 


\subsection{Treatment impacts biochemical parameters.}

Aspartate transaminase (AST) was increased in the DMBA control group and the doxorubicin-treated group compared to the normal group, but the level was normal in the EAIH-treated group. This can be attributed to the toxic effect on the liver from DMBA and doxorubicin. In both the DMBA and doxorubicin treatment groups, the level of urea was significantly increased compared to the normal control groups. However, the level of urea was almost normal in groups with EAIH. There were no significant alterations in the levels of alanine aminotransferase (ALT) and creatinine in any group (Table 4).

Table 4. The impacts of treatments in Sprague Dawley rats on serum biochemical parameters.

\begin{tabular}{l|l|l|l|l}
\hline Groups & Urea $(\mathbf{m g} / \mathbf{d L})$ & $\begin{array}{l}\text { Creatinine } \\
(\boldsymbol{\mu} \mathbf{m o l} / \mathbf{L})\end{array}$ & $\mathbf{A S T}(\mathbf{U} / \mathbf{L})$ & ALT $(\mathbf{U} / \mathbf{L})$ \\
\hline Normal Control & $27.83 \pm 0.64$ & $31.24 \pm 0.32$ & $127.83 \pm 2.22^{\mathrm{a}}$ & $63.34 \pm 0.34$ \\
\hline DMBA control & $35.13 \pm 0.39$ & $30.34 \pm 0.42$ & $153.36 \pm 1.63^{\mathrm{a}}$ & $62.76 \pm 0.32$ \\
\hline Doxorubicin & $33.25 \pm 0.25$ & $30.15 \pm 0.25$ & $159.63 \pm 2.25^{\mathrm{a}}$ & $60.34 \pm 1.73$ \\
\hline EAIH $25 \mathrm{mg} / \mathrm{kg}$ & $30.76 \pm 0.54$ & $29.23 \pm 0.27$ & $128.53 \pm 2.53^{\mathrm{a}}$ & $62.64 \pm 0.35$ \\
\hline EAIH 50mg/kg & $29.65 \pm 0.75$ & $31.86 \pm 0.33$ & $131.74 \pm 1.48^{\mathrm{a}}$ & $63.97 \pm 0.85$ \\
\hline
\end{tabular}

All the values are given as mean \pm SEM; ${ }^{\mathrm{a}} p<0.05$ compared to Normal control; $n=6$.

3.6. Treatment impact on levels of nitrate and nitrite in breast tissue.

The levels of nitrate and nitrites were elevated in the DMBA-treated control group, indicating oxidative stress. However, the levels for all other treatment groups were near normal (Figure 3).

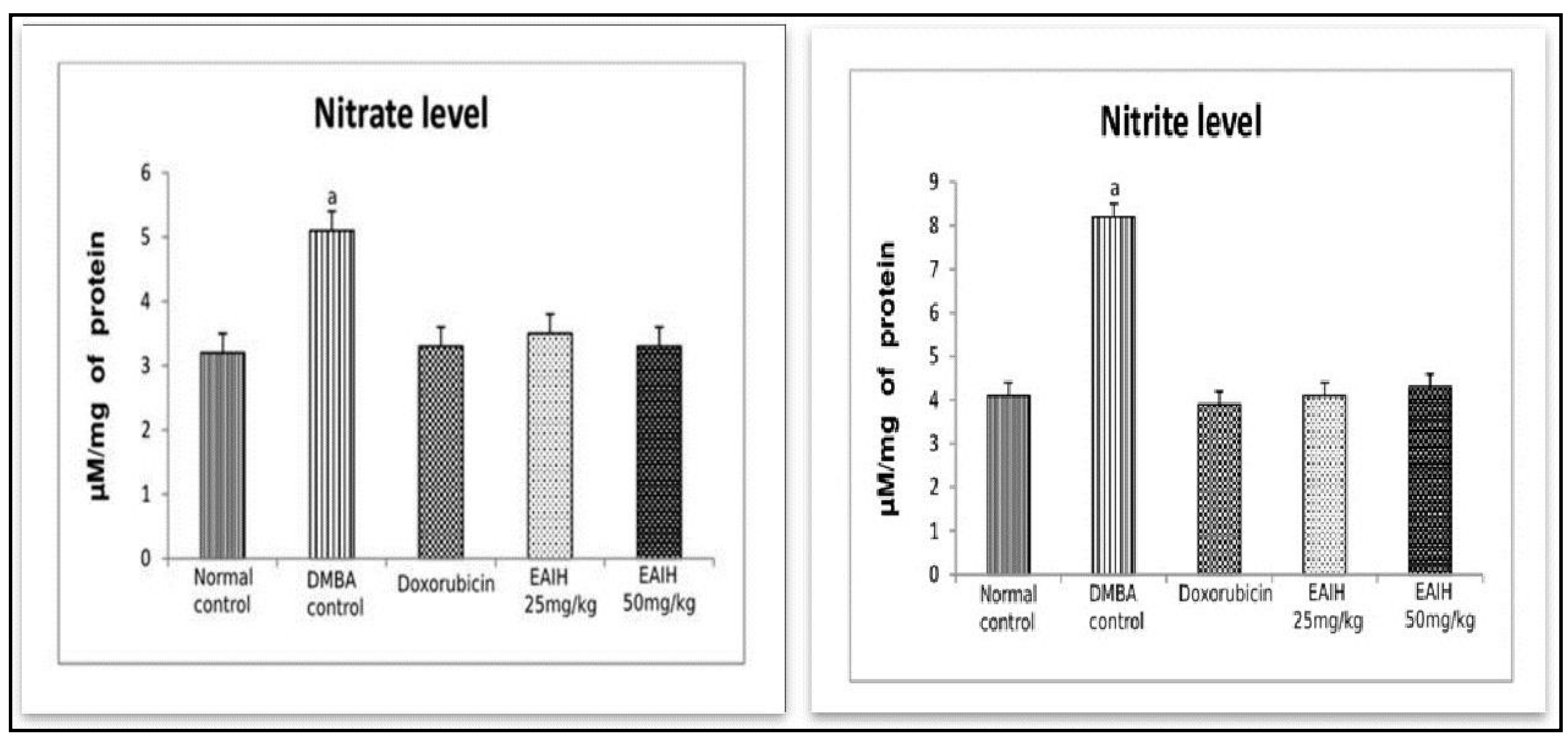

Figure 3. Treatment impact on nitrate, nitrite levels in the breast tissue treated with EAIH. All the values are expressed as mean $\pm \mathrm{SEM}$; ap $<0.05$ compared to Normal control; $\mathrm{n}=6$.

\subsection{Histopathology studies on breast tissue.}

Tissue infiltrated into lobules, abundant fibrous stroma, and proliferated ductules were shown in breast tissue sections from the DMBA control tumor groups. In large areas, necrosis has been recognized as well. These typical characteristics have been designated as invasive ductal carcinoma. The breast tissues collected from doxorubicin-treated rats showed less necrosis and infiltration; similarly, the EAIH $25 \mathrm{mg} / \mathrm{kg}$ and EAIH $50 \mathrm{mg} / \mathrm{kg}$ tested samples also showed less necrosis and infiltration. Some of the damaged breast patterns were refurbished to normal by the treatments (Figure 4). 


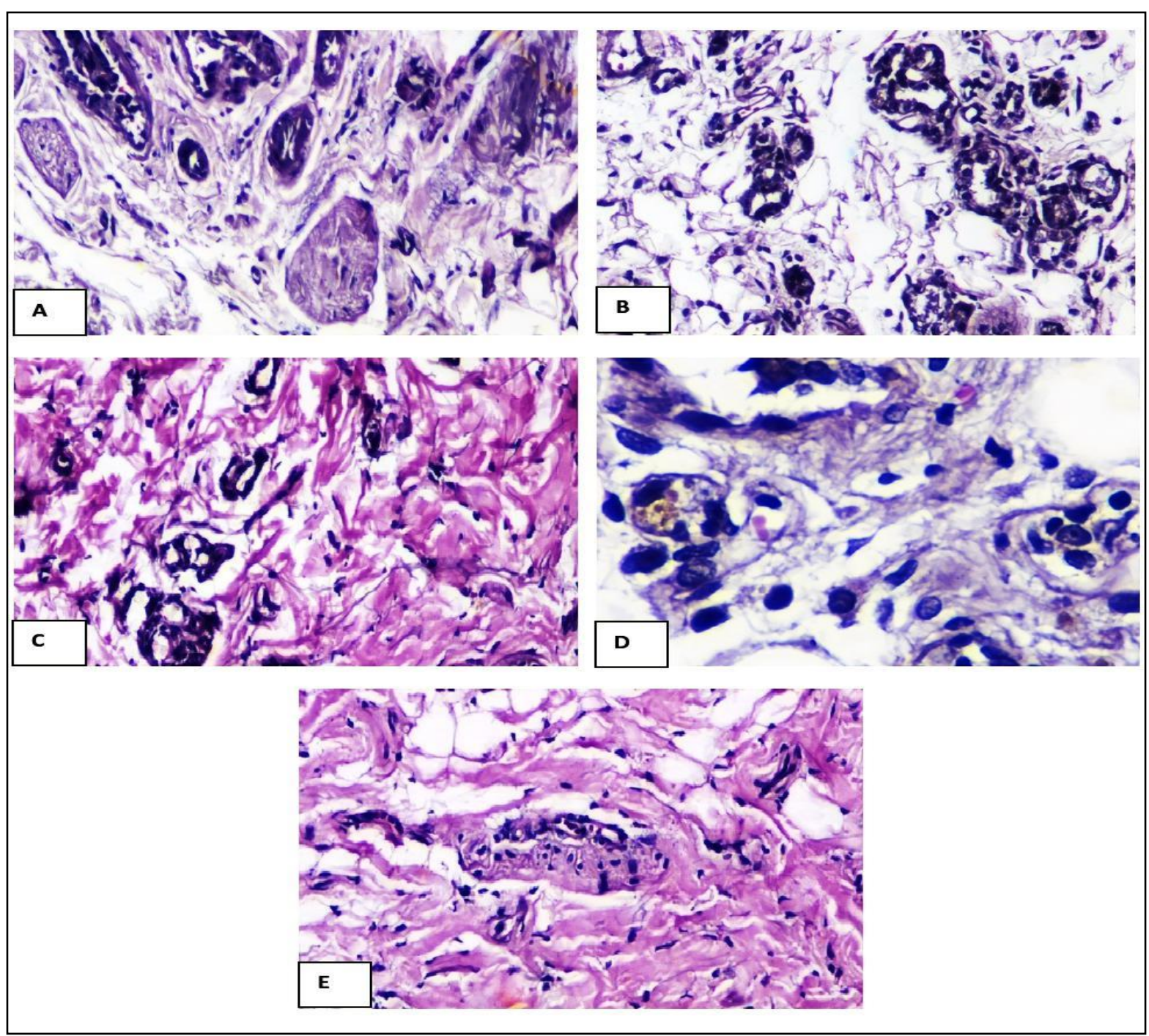

Figure 4. Breast tissues histopathology: A- Normal control animals, B, C, D, E, denote DMBA control, doxorubicin, EAIH $25 \mathrm{mg} / \mathrm{kg}$, and EAIH $50 \mathrm{mg} / \mathrm{kg}$ treated groups respectively (observed under 40×).

Currently, breast cancer is a common neoplasm among females and has a great level of occurrence of mortality [30]. At present, breast cancer managements consist of surgery, chemo medications, radiation therapy, hormone, and immunotherapy, though these remedies have many toxic effects [31]. Herbal products are used and examined to identify and enhance therapeutic anticancer agents. The use of animal models in experiments is mostly valuable for learning about human mammary cancer. To induce a tumor, we employed a single dosage (30 $\mathrm{mg} / \mathrm{kg}$ ) of 7, 12-dimethylbenz (a) anthracenes (DMBA) produced in olive oil administered using an intragastric tube. The ductal region of the human breast is where malignant growth begins, and the DMBA-induced mammary tumor model follows the same [32]. DMBAinstigated carcinogenesis had been recorded to be related to ductal carcinoma, fibroadenoma, and papilloma [33]. Multiplication in human breast carcinomas occurs predominantly in epithelial cells $[34,35,36]$. Therefore, the rat model is a precious animal model for human breast cancer studies. The mammalian rat glans then have a good chance of developing neoplasms that closely imitate human breast cancer [37]. The toxicity of DMBA is due to its oxidative metabolism, which produces free radicals that bind to nucleophilic sites via covalently connecting with cellular macromolecules, producing carcinogenic processes. Our research used two dosages of $25 \mathrm{mg} / \mathrm{kg}$ and $50 \mathrm{mg} / \mathrm{kg}$ EAIH body weight. Doxorubicin was chosen as the reference medicine (standard), and it was given at a dose of $2 \mathrm{mg} / \mathrm{kg}$ i. p. Animals treated 
with EAIH at any dose had no significant increases in body weight or organs such as the kidney, liver, spleen, or heart, according to the findings. All of the EAIH animals treated showed a significant reduction in tumor volume and weight compared to the DMBA control rats.

The free radicals and their biochemical reactions are part of cancer growth at each metabolic stage [38]. Herbal polyphenols have been shown to have anticancer properties in previous studies, particularly in human cancer cells [39,40,41]. Carcinogenesis has been linked to oxidative stress, specifically lipid peroxidation $[42,43]$. Catalase is found throughout the body and causes hydrogen peroxide to break down in tumor cells. SOD and catalase levels have been found to drop in a variety of carcinogenic situations [44]. The decisive result of lipid peroxidation, malondialdehyde (MDA), was shown to be higher in carcinomatous tissue than in normal tissue [45]. A raised degree of lipid peroxide level in the control group reflects the overproduction of free radicals and the failure of the antioxidant protection system to execute sufficiently during the occasion of tumor growth [46].

RBC and hemoglobin levels in doxorubicin-treated rats were considerably lower than in normal control groups in our study. This could have been an immediate result of doxorubicin's bone marrow poisoning. Lipid peroxidation in tissues can reveal the degree of oxidative danger [47]. The levels of MDA in the breast tissue were measured, and the DMBA control and doxorubicin-given groups had significantly higher amounts than the normal control animals. When compared to normal control, the change in MDA levels in EAIH treated groups was not significant. In comparison to the normal animal group, the amount of breast tissue catalase in the DMBA control and doxorubicin controlled groups was significantly reduced. A high sensitivity-free radical present within the body is nitric oxide (NO) which causes malignant growth and genotoxicity [48]. NO's metabolites, such as nitrate and nitrite, can be measured in physiological fluids and tissues. The DMBA control groups' nitrate and nitrite levels showed signs of oxidative stress, and the levels were found to be higher in those groups in our investigation. The levels of nitrate and nitrite were found to be close to normal in EAIHtreated groups. The scavenging of NO by antioxidant phytoconstituents present may have been the work for this plant. According to the literature review, several plant extracts and isolated compounds such as M. capitatum [49], M. trifoliate [50], P. santalinus [51], A. annua [52], S. vulgare [53], C. Cupreum [54], C. formicarum [55], C. indicum [56], C. glabrum [57], C. viscosum [58], F. grahamiana [59], W. Somnifera [60], C. Annuum [61], A. elata [62], etc., were reported for anticancer activity

In our investigation, the breast tissues from the rats treated with standard drug doxorubicin and the tested sample EAIH $25 \mathrm{mg} / \mathrm{kg}$ and EAIH $50 \mathrm{mg} / \mathrm{kg}$ showed less necrosis and infiltration in a dose-dependent way. The EAIH therapies were able to restore some of the typical breast patterns. Herbal remedies have long been a rich source of chemotherapeutic drugs, and $I$. horsfalliae could be an anticancer candidate.

\section{Conclusions}

The current study suggests that EAIH may have inhibitory effects on DMBA-induced breast cancers, which could be attributed to the phytochemicals found in this plant. The antioxidant components in EAIH may be responsible for its ability to reduce DMBA-induced oxidative damage. More research is being done to extract and demonstrate the promising elements that contribute to its anticancer properties. 


\section{Funding}

This research received no external funding.

\section{Acknowledgments}

The authors are grateful to all colleagues for their extensive support.

\section{Conflicts of Interest}

The authors declare no conflict of interest.

\section{References}

1. Wang, J.; Ye, C.; Xiong, H.; Shen, Y.; Lu, Y.; Zhou, J.; Wang, L. Dysregulation of long non-coding RNA in breast cancer: an overview of mechanism and clinical implication. Oncotarget 2017, 8, 5508-5522, https://dx.doi.org/10.18632/oncotarget.12537.

2. Torre, L.A.; Bray, F.; Siegel, R.L.; Ferlay, J.; Lortet-Tieulent, J.; Jemal, A. Global cancer statistics, 2012: Global Cancer Statistics, 2012.CA Cancer J. Clin. 2015, 65, 87-108, https://dx.doi.org/10.3322/caac.21262.

3. Hanahan, D.; Weinberg, R.A. Hallmarks of cancer: the next generation. Cell 2011, 144, 646-674, https://dx.doi.org/10.1016/j.cell.2011.02.013.

4. Welti, J.; Loges, S.; Dimmeler, S.; Carmeliet, P. Recent molecular discoveries in angiogenesis and antiangiogenic therapies in cancer. J. Clin. Invest. 2013, 123, 3190-3200, https://dx.doi.org/10.1172/jci70212.

5. Esquivel-Velázquez, M.; Ostoa-Saloma, P.; Palacios-Arreola, M.I.; Nava-Castro, K.E.; Castro, J.I.; MoralesMontor, J. The role of cytokines in breast cancer development and progression. J. Interferon Cytokine Res. 2015, 35, 1-16, https://doi.org/10.1089/jir.2014.0026.

6. Gullino, P.M.; Pettigrew, H.M.; Grantham, F.H. N-nitrosomethylurea as mammary gland carcinogen in rats. J. Natl. Cancer Inst. 1975, 54, 401-414, https://dx.doi.org/10.1093/jnci/54.2.401.

7. Wattenberg, L.W. Chemoprevention of cancer. Prev. Med. 1996, 25, 44-45, https://dx.doi.org/10.1006/pmed.1996.0015.

8. Abba, M.C.; Zhong, Y.; Lee, J.; Kil, H.; Lu, Y.; Takata, Y.; Simper, M.S.; Gaddis, S.; Shen, J.; Aldaz, C.M. DMBA induced mouse mammary tumors display high incidence of activating Pik3caH1047 and loss of function Pten mutations. Oncotarget 2016, 7, 64289-64299, https://doi.org/10.18632/oncotarget.11733.

9. Sharma, S.; Stutzman, J.D.; Kelloff, G.J.; Steele, V.E. Screening of potential chemopreventive agents using biochemical markers of carcinogenesis. Cancer Res. 1994, 54, 5848-5855.

10. Anderson, M.E.; Meister, A. Transport and direct utilization of gamma-glutamylcyst(e)ine for glutathione synthesis. Proc. Natl. Acad. Sci. U. S. A. 1983, 80, 707-711, https://dx.doi.org/10.1073/pnas.80.3.707.

11. Sun, Y. Free radicals, antioxidant enzymes, and carcinogenesis. Free Radic. Biol. Med. 1990, 8, 583-599, https://dx.doi.org/10.1016/0891-5849(90)90156-d.

12. Fossati, R.; Confalonieri, C.; Torri, V.; Ghislandi, E.; Penna, A.; Pistotti, V.; Tinazzi, A.; Liberati, A. Cytotoxic and hormonal treatment for metastatic breast cancer: a systematic review of published randomized trials involving $31,510 \quad$ women. J. Clin. Oncol. 1998, 16, 3439-3460, https://dx.doi.org/10.1200/jco.1998.16.10.3439.

13. Early Breast Cancer Trialists' Collaborative Group (EBCTCG) Effects of chemotherapy and hormonal therapy for early breast cancer on recurrence and 15-year survival: an overview of the randomised trials. Lancet 2005, 365, 1687-1717, https://dx.doi.org/10.1016/s0140-6736(05)66544-0.

14. Nounou, M.I.; ElAmrawy, F.; Ahmed, N.; Abdelraouf, K.; Goda, S.; Syed-Sha-Qhattal, H. Breast cancer: Conventional diagnosis and treatment modalities and recent patents and technologies. Breast Cancer (Auckl.) 2015, 9, 17-34, https://dx.doi.org/10.4137/bcbcr.s29420.

15. The American cancer society's principles of oncology: Prevention to survivorship; The American Cancer Society, Ed.; John Wiley \& Sons, Inc.: Hoboken, NJ, USA, 2018; ISBN 9781119468868, https://doi.org/10.1002/9781119468868. 
16. Delgado Júnior, G.C.; Buril, M.T.; Alves, M. Convolvulaceae do Parque Nacional do Catimbau, Pernambuco, Brasil. Rodriguésia 2014, 65, 425-442, $\quad$ https://dx.doi.org/10.1590/s217578602014000200008.

17. Austin, D.F.; Huáman, Z. A synopsis of Ipomoea (Convolvulaceae) in the Americas. Taxon 1996, 45, 3-38, https://doi.org/10.2307/1222581.

18. Sierra, L.J.; Córdoba, Y.; Mejía, J.J.; Rueda, E.Q.; Ocazionez, R.E.; Avila-Acevedo, J.G.; García-Bores, A.M.; Espinosa-González, A.M.; del Carmen Benítez-Flores, J.; del Rosario González-Valle, M.; et al. Photoprotective Activity of Ipomoea horsfalliae Flower Extract. Rev. Bras. Farmacogn. 2020, 30, 69-79, https://doi.org/10.1007/s43450-020-00024-6.

19. Lu, Y.; Priyantha, N.; Lim, L.B.L. Ipomoea aquatica roots as environmentally friendly and green adsorbent for efficient removal of Auramine O dye. Surf. Interfaces 2020, 20, 100543, https://doi.org/10.1016/j.surfin.2020.100543.

20. Rojas-Idrogo, C.; Kato, M.J.; Delgado-Paredes, G.E.; Floh, E.I.S.; Handro, W. Production of secondary metabolites in in vitro root cultures and cellular suspension of Ipomoea carnea spp. carnea Jacq. An. Biol. 2014, https:/doi.org/10.6018/analesbio.36.18.

21. Takao, L.K.; Ribeiro, J.P.N.; Lima, M.I.S. Allelopathic effects of Ipomoea cairica (L.) Sweet on crop weeds. Acta Bot. Brasilica 2011, 25, 858-864, https://doi.org/10.1590/s0102-33062011000400012.

22. Bah, M.; Pereda-Miranda, R. Isolation and structural characterization of new glyclipid ester type dimers from the resin of Ipomoea tricolor (Convolvulaceae). Tetrahedron 1997, 53, 9007-9022, https://doi.org/10.1016/s0040-4020(97)00607-8.

23. Jain, A.; Joshi, A.; Joshi, N. Allelopathic Potential and HPTLC Analysis of Ipomoea carnea. Int. j. life-sci. sci. res. 2017, 3, 1278-1282.

24. Muhammed Ashraf, V.K.; Kalaichelvan, V.K.; Venkatachalam, V.V.; Ragunathan, R. In vitro anticancer potential of aerial parts of Ipomoea horsfalliae hook in different human cancer cell lines. Ind. Crops Prod. 2020, 155, 112746, https://dx.doi.org/10.1016/j.indcrop.2020.112746.

25. Shoja, M.H.; Reddy, N.D.; Nayak, P.G.; Biswas, S.; Srinivasan, K.K.; Rao, C.M. In vitro mechanistic and in vivo anti-tumor studies of Glycosmis pentaphylla (Retz.) DC against breast cancer. $J$. Ethnopharmacol. 2016, 186, 159-168, http://dx.doi.org/10.1016/j.jep.2016.04.002.

26. Arivazhagan, L.; Sorimuthu Pillai, S. Tangeretin, a citrus pentamethoxyflavone, exerts cytostatic effect via p53/p21 up-regulation and suppresses metastasis in 7,12-dimethylbenz $(\alpha)$ anthracene-induced rat mammary carcinoma. J. Nutr. Biochem. 2014, 25, 1140-1153, https://dx.doi.org/10.1016/j.jnutbio.2014.06.007.

27. Miranda, K.M.; Espey, M.G.; Wink, D.A. A rapid, simple spectrophotometric method for simultaneous detection of nitrate and nitrite. Nitric Oxide 2001, 5, 62-71, https://dx.doi.org/10.1006/niox.2000.0319.

28. Ohkawa, H.; Ohishi, N.; Yagi, K. Assay for lipid peroxides in animal tissues by thiobarbituric acid reaction. Anal. Biochem. 1979, 95, 351-358. http://dx.doi.org/10.1016/0003-2697(79)90738-3.

29. Cohen, G.; Dembiec, D.; Marcus, J. Measurement of catalase activity in tissue extracts. Anal. Biochem. 1970, 34, 30-38, https://dx.doi.org/10.1016/0003-2697(70)90083-7.

30. Stimpfel, M.; Virant-Klun, I. Cancer incidence and mortality worldwide: sources, methods and major patterns in GLOBOCAN 2012.J. Cancer Stem Cell Res. 2016, 4, 1, https://dx.doi.org/10.14343/jcscr.2016.4e1003.

31. Ferlay, J.; Soerjomataram, I.; Dikshit, R.; Eser, S.; Mathers, C.; Rebelo, M.; Parkin, D.M.; Forman, D.; Bray, F. Cancer incidence and mortality worldwide: sources, methods and major patterns in GLOBOCAN 2012: Globocan 2012. Int. J. Cancer 2015, 136, E359-86, https://dx.doi.org/10.14343/jcscr.2016.4e1003.

32. Costa, I.; Solanas, M.; Escrich, E. Histopathologic characterization of mammary neoplastic lesions induced with 7,12 dimethylbenz(alpha)anthracene in the rat: a comparative analysis with human breast tumors. Arch. Pathol. Lab. Med. 2002, 126, 915-927, https://doi.org/10.5858/2002-126-0915-HCOMNL.

33. Barros, A.C.S.D.; Muranaka, E.N.K.; Mori, L.J.; Pelizon, C.H.T.; Iriya, K.; Giocondo, G.; Pinotti, J.A. Induction of experimental mammary carcinogenesis in rats with 7,12-dimethylbenz(a)anthracene. Rev. Hosp. Clin. Fac. Med. Sao. Paulo. 2004, 59, 257-261, https://dx.doi.org/10.1590/s004187812004000500006.

34. Clarke, R. Issues in experimental design and endpoint analysis in the study of experimental cytotoxic agents in vivo in breast cancer and other models. Breast Cancer Res. Treat. 1997, 46, 255-278, https://dx.doi.org/10.1023/a:1005938428456. 
35. Russo, J.; Hasan Lareef, M.; Balogh, G.; Guo, S.; Russo, I.H. Estrogen and its metabolites are carcinogenic agents in human breast epithelial cells. J. Steroid Biochem. Mol. Biol. 2003, 87, 1-25, https://dx.doi.org/10.1016/s0960-0760(03)00390-x.

36. Balogh, G.A.; Russo, I.H.; Russo, J. Mutations in mismatch repair genes are involved in the neoplastic transformation of human breast epithelial cells. Int. J. Oncol. 2003, 23, 411-419, https://dx.doi.org/10.3892/ijo.23.2.411.

37. Flohé, L.; Otting, F. Superoxide dismutase assays. Methods Enzymol. 1984, 105, 93-104, https://dx.doi.org/10.1016/s0076-6879(84)05013-8.

38. Kwon, K.-Y.; Jang, J.-H.; Kwon, S.-Y.; Cho, C.-H.; Oh, H.-K.; Kim, S.-P. Cadmium induced acute lung injury and TUNEL expression of apoptosis in respiratory cells. J. Korean Med. Sci. 2003, 18, 655-662, https://dx.doi.org/10.3346/jkms.2003.18.5.655.

39. Haghiac, M.; Walle, T. Quercetin induces necrosis and apoptosis in SCC-9 oral cancer cells. Nutr. Cancer 2005, 53, 220-231, https://dx.doi.org/10.1207/s15327914nc5302_11.

40. Vidya Priyadarsini, R.; Senthil Murugan, R.; Maitreyi, S.; Ramalingam, K.; Karunagaran, D.; Nagini, S. The flavonoid quercetin induces cell cycle arrest and mitochondria-mediated apoptosis in human cervical cancer

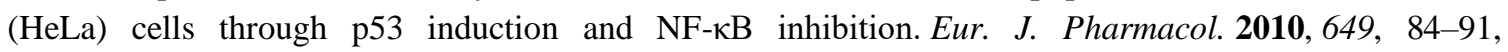
https://dx.doi.org/10.1016/j.ejphar.2010.09.020.

41. Bishayee, K.; Ghosh, S.; Mukherjee, A.; Sadhukhan, R.; Mondal, J.; Khuda-Bukhsh, A.R. Quercetin induces cytochrome-c release and ROS accumulation to promote apoptosis and arrest the cell cycle in G2/M, in cervical carcinoma: signal cascade and drug-DNA interaction. Cell Prolif. 2013, 46, 153-163, https://dx.doi.org/10.1111/cpr.12017.

42. Trush, M.A.; Kensler, T.W. An overview of the relationship between oxidative stress and chemical carcinogenesis. Free $\quad$ Radic. Biol. $\quad$ Med. 1991, 10, 201-209, https://dx.doi.org/10.1016/08915849(91)90077-g.

43. Rice-Evans, C.; Burdon, R. Free radical-lipid interactions and their pathological consequences. Prog. Lipid Res. 1993, 32, 71-110, https://dx.doi.org/10.1016/0163-7827(93)90006-i.

44. Thirunavukkarasu, C.; Sakthisekaran, D. Effect of selenium on N-nitrosodiethylamine-induced multistage hepatocarcinogenesis with reference to lipid peroxidation and enzymic antioxidants. Cell Biochem. Funct. 2001, 19, 27-35, https://dx.doi.org/10.1002/cbf.895.

45. Yagi, K. Lipid peroxides and human diseases. Chem. Phys. Lipids 1987, 45, 337-351, https://dx.doi.org/10.1016/0009-3084(87)90071-5.

46. Vasavi, H.; Thangaraju, M.; Sachdanandam, P. Effect of ?-tocopherol on lipid peroxidation and antioxidant system in fibrosarcoma bearing rats. Mol. Cell. Biochem. 1994, 131, 125-129, https://dx.doi.org/10.1007/bf00925948.

47. Janero, D.R. Malondialdehyde and thiobarbituric acid-reactivity as diagnostic indices of lipid peroxidation and peroxidative tissue injury. Free Radic. Biol. Med. 1990, 9, 515-540, https://dx.doi.org/10.1016/08915849(90)90131-2.

48. Vakkala, M.; Kahlos, K.; Lakari, E.; Pääkkö, P.; Kinnula, V.; Soini, Y. Inducible nitric oxide synthase expression, apoptosis, and angiogenesis in in situ and invasive breast carcinomas. Clin. Cancer Res. 2000, 6, 2408-2416.

49. Ukwubile, C.A.; Ikpefan, E.O.; Malgwi, T.S.; Bababe, A.B.; Odugu, J.A.; Angyu, A.N.; Otalu, O.; Bingari, M.S.; Nettey, H.I. Cytotoxic effects of new bioactive compounds isolated from a Nigerian anticancer plant Melastomastrum capitatum Fern. leaf extract. Scientific African 2020, 8, e00421, https://dx.doi.org/10.1016/j.sciaf.2020.e00421.

50. Kowalczyk, T.; Sitarek, P.; Skała, E.; Toma, M.; Wielanek, M.; Pytel, D.; Wieczfińska, J.; Szemraj, J.; Śliwiński, T. Induction of apoptosis by in vitro and in vivo plant extracts derived from Menyanthes trifoliata L. in human cancer cells. Cytotechnology 2019, 71, 165-180, https://dx.doi.org/10.1007/s10616-018-02749.

51. Akhouri, V.; Kumar, A.; Kumari, M. Antitumour property ofPterocarpus santalinusSeeds against DMBAinduced breast cancer in rats. Breast Cancer (Auckl.) 2020, 14, 117822342095119, https://dx.doi.org/10.1177/1178223420951193.

52. M. Faheem, H.M.; M. Elnbtete, S.M. Artemisia annua Extract Ameliorates DMBA-induced Breast Cancer in Albino rats; Antioxidant and Genetic Effects. Orient. J. Chem. 2020,36, 451-457, https://dx.doi.org/10.13005/ojc/360314. 
53. Brantley, A.U. Effect of selected plants on Haematological parameters of DMBA-induced breast cancer of albino rats. International Journal of Biochemistry \& Physiology 2019, 4, http://dx.doi.org/10.23880/ijbp16000151.

54. Tirumale, S.; Wani, N.; Khanday, W.; Ali, S. Biological evaluation of ethyl acetate extract of Chaetomium cupreum against Ehrlich ascites carcinoma cells in Swiss albino mice. Egypt. Pharm. J. 2020, 19, 274, https://dx.doi.org/10.4103/epj.epj_29_20.

55. Mwene-Mbeja, T.M.; Spino, C.; Poirier, D.; Mutombo, E.K.; Roy, J.; Mulowayi, K.; Kaseya, K.; Kitambala, M.M.; Gagnon, R.; Mwene-Mbeja, T.M. Evaluation of Anticancer Activities of Clerodendrum formicarum Gurke (Lamiaceae) and Syzygium Cordatum Hochst ex Krauss (Myrtaceae) Harvested in the City of Lubumbashi and its Surroundings in the Democratic Republic Of The Congo. Clinical Microbiology and Research 2020, 1-5, https://dx.doi.org/10.31487/j.cmr.2020.01.04.

56. Priya, K.; Setty, M.M.; Pai, K.S.R. In vitro and In vivo Evaluation of Anticancer Properties of Clerodendrum indicum (L.) Kuntze in Colon Cancer. Res. J. Pharm. Technol. 2020, 13, 2321, https://dx.doi.org/10.5958/0974-360x.2020.00418.7.

57. Teclegeorgish, Z.W.; Mokgalaka, N.S.; Vukea, N.; de la Mare, J.-A.; Tembu, V.J. Cytotoxicity of triterpenoids from Clerodendrum glabrum against triple negative breast cancer cells in vitro. S. Afr. J. Bot. 2020, 133, 144-150, https://dx.doi.org/10.1016/j.sajb.2020.07.009.

58. Shendge, A.K.; Chaudhuri, D.; Basu, T.; Mandal, N. A natural flavonoid, apigenin isolated from Clerodendrum viscosum leaves, induces G2/M phase cell cycle arrest and apoptosis in MCF-7 cells through the regulation of p53 and caspase-cascade pathway. Clin. Transl. Oncol. 2021, 23, 718-730, https://dx.doi.org/10.1007/s12094-020-02461-0.

59. Chemical Compositions and Anticancer Activity of Yemeni Plant Flemingia grahamiana Wight \& Arn. and Myrtus communis L. Tropical Journal of Natural Product Research 2021,5, 877-882, https://dx.doi.org/10.26538/tjnpr/v5i5.14.

60. Dhabian, S.; Jasim, R. Anticancer and antioxidant activity of the greenly synthesized zinc nanoparticles composites using aqueous extract of Withania somnifera plant. Egypt. J. Chem. 2021, 0, 0-0, http://dx.doi.org/10.21608/ejchem.2021.75114.3686.

61. Promising cytotoxicity and anticancer activity of capsicum annuum. Indian j. forensic med. toxicol. 2021, https://dx.doi:10.37506/ijfmt.v15i3.15570.

62. Lee, J.-H. Suppression of cellular adhesion and the anticancer activity of Aralia elata extract. Food Sci. Technol. 2021, https://dx.doi:10.1590/fst.30821. 